\title{
Omental Cyst - Rare Cause of Abdominal Pain in a 7-Year-Old Child: A Case Report
}

\author{
Maimuna Sayeed ${ }^{\mathrm{a}} \quad$ Md Benzamin $^{\mathrm{a}}$ Sharmin Akter $^{\mathrm{a}}$ \\ Md. Wahiduzzaman Mazumder ${ }^{\mathrm{a}}$ A.S.M. Bazlul Karim ${ }^{\mathrm{a}}$ Bishnu Pada Dey ${ }^{\mathrm{b}}$ \\ a Department of Pediatric Gastroenterology and Nutrition, Bangabandhu Sheikh Mujib Medical University (BSMMU), \\ Dhaka, Bangladesh; ${ }^{\mathrm{b}}$ Department of Pathology, Faculty of Basic Science and Paraclinical Science, Bangabandhu \\ Sheikh Mujib Medical University (BSMMU), Dhaka, Bangladesh
}

\section{Keywords}

Omental cyst in children - Mesenteric cyst in children .

Abdominal pain in children

\section{Abstract}

Introduction: Abdominal pain is a common complaint in children. In most cases it may be functional. Among all organic causes, an abdominal cyst of omental or mesenteric origin is an uncommon etiology. Case Presentation: A 7-year-old girl presented with a short history of abdominal pain for 1 month associated with gradual abdominal distention. Physical examination revealed a large oval palpable firm, non-tender mass extending almost the whole abdomen. Imaging studies were suggestive of an intra-abdominal cyst, and the diagnosis was confirmed after exploratory laparotomy. The patient was managed surgically by enucleation of the cyst. Conclusion: Omental cysts are a rare benign condition, but should be considered as a diagnostic hypothesis in children with abdominal pain with or without a mass. It is difficult to diagnose an omental/mesenteric cyst clinically. A proper imaging study can guide the diagnosis. After confirming the diagnosis, the main treatment would be surgical excision.

(c) 2020 Sociedade Portuguesa de Gastrenterologia Published by S. Karger AG, Basel

karger@karger.com www.karger.com/pjg

Karger!

bOPEN ACCESS
(C) 2020 Sociedade Portuguesa de Gastrenterologia Published by S. Karger AG, Basel

This article is licensed under the Creative Commons AttributionNonCommercial-NoDerivatives 4.0 International License (CC BYNC-ND) (http://www.karger.com/Services/OpenAccessLicense). Usage and distribution for commercial purposes as well as any distribution of modified material requires written permission.

\section{Quisto epiplóico - Causa rara de dor abdominal numa criança de 7 anos: um caso clínico}

\author{
Palavras Chave \\ Dor abdominal · Quisto epiplóico · Dor · Cirurgia · \\ Ecografia
}

\section{Resumo}

Introdução: A dor abdominal é um sintoma comum durante a infância, mas na maioria dos casos é funcional. Entre as causas orgânicas potenciais, os quistos abdominais de origem epiplóica ou mesentérica são raros. Caso Clínico: Uma menina de 7 anos de idade desenvolveu um quadro clínico caracterizado por dor e distensão abdominal gradual, com aproximadamente 1 mês de evolução. 0 exame objetivo revelou uma massa abdominal oval, de grandes dimensões, de consistência firme, mas indolor. Os estudos imagiológicos sugeriram a presença de um quisto intra-abdominal que se confirmou durante uma laparotomia exploradora. O tratamento foi cirúrgico e consistiu na enucleação do quisto. Conclusões: Os quistos epiplóicos são uma condição benigna rara, mas devem ser considerados no diagnóstico diferencial em cri- 
anças com dor abdominal, independentemente da presença de uma massa. O diagnóstico semiológico é difícil, mas um estudo imagiológico adequado pode ser esclarecedor. Após confirmação do diagnóstico a excisão cirúrgica é a modalidade terapêutica de eleição.

(C) 2020 Sociedade Portuguesa de Gastrenterologia Publicado por S. Karger AG, Basel

\section{Introduction}

Omental and mesenteric cysts are rare intra-abdominal lesions in the pediatric population [1]. These lesions are the same entity, differing only in location. The incidence of omental and mesenteric cysts is 1 in 20,000 among children and lower in infants and of these cystic masses $2.2 \%$ are omental cysts [2]. The etiology of these benign cysts remains unknown but several theories exist regarding their development. The treatment of choice is complete surgical excision of the cyst. Since it is a rare condition and there are lack of specific symptoms, a correct pre-operative diagnosis is difficult. Due to the various complications associated with suboptimal surgical management, knowledge of these lesions is important.

\section{Case Report}

A 7-year-old girl presented to the Department of Pediatric Gastroenterology and Nutrition of the Bangabandhu Sheikh Mujib Medical University (BSMMU) with complaints of diffuse, dull abdominal pain for 1 month duration. Pain and distension were mostly in the middle and left side of the abdomen. The pain was associated with gradual abdominal distension. It was not related to taking food, and there was no history of vomiting. Her growth and development were normal. There was no history of fever, jaundice, or any bleeding manifestation. There was no history of contact with a person with tuberculosis, any abdominal trauma. She had no loss of appetite, no family history of similar illness.

Physical examination revealed that she was mildly pale, anicteric, no edema, vitals were within normal limit, no lymphadenopathy, and anthropometry was in a normal range. Abdomen was distended with a large, non-tender smooth surface, and a well-defined border, movable from side to side (Fig. 1). Laboratory investigation revealed hemoglobin $10.49 \mathrm{gm} / \mathrm{dL}$, erythrocyte sedimentation rate $59 \mathrm{~mm}$ in the first hour, total count $13,200 / \mathrm{cm}^{3}$, neutrophil $64 \%$, lymphocyte $30 \%$, eosinophil $4 \%$, basophil $2 \%$, and platelet $550,000 / \mathrm{cm}^{3}$. Urinalysis was normal. Ultrasonogram of the whole abdomen revealed a large cystic mass lesion with internal septations, loculi and low-level echo in the pelvic cavity (mainly on the left side) with extending up to the epigastric region. Other abdominal organs were normal. The

Omental Cyst - Rare Cause of Abdominal Pain in a 7-Year-Old Child

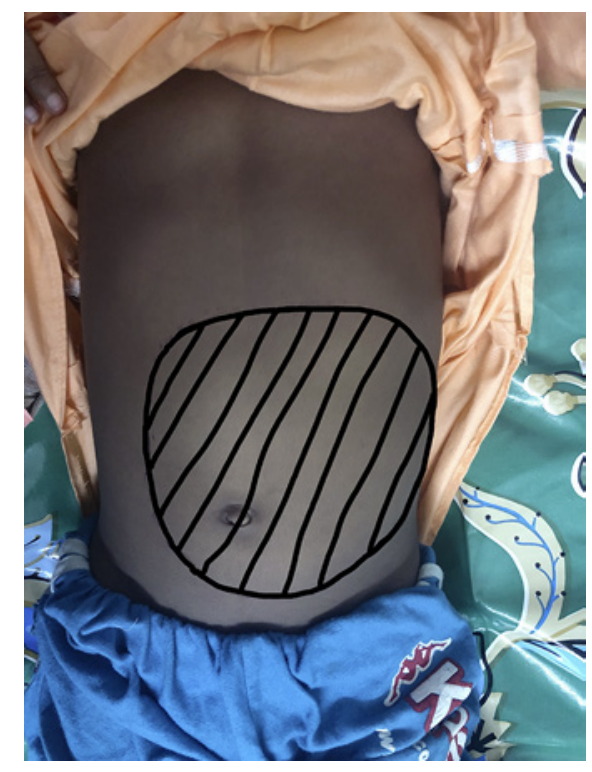

Fig. 1. The abdomen was distended.

test for echinococcus antigen was negative. According to the ultrasonogram finding of the large septated cystic mass lesion that is shown in Figure 2, the differential diagnoses were ovarian cystadenoma, encapsulated ascites, and retroperitoneal lymphangiectasis.

High-dose contrast-enhanced computed tomography (CECT) of the whole abdomen revealed a well-defined thin-walled large cystic area measuring about $(19 \mathrm{~cm}) \times($ anterior-posterior $9 \mathrm{~cm}) \times$ (transverse diameter $14 \mathrm{~cm}$ ) seen at center and upper left abdomen. The lesion had internal septa and scattered hypodense areas, causing compression and displacement of the pancreas posteriorly, the body of stomach superiorly, and bowel loops peripherally. After intravenous contrast administration, no abnormal enhancement was noted (Fig. 3). There was the impression of a large cystic mass in the abdominal cavity with extensions into an abovementioned area and dimensions, possibly a mesenteric cyst. Based on the clinical feature and CECT report, the diagnosis was a huge mesenteric cyst in the abdomen with mass effect.

Exploratory laparotomy was done for excision and biopsy. A large cyst with hemorrhagic fluid and debris, arising from the greater omentum in the region of the transverse colon was found (see Fig. 4, 5). It was enucleated, leaving the intestine intact. The post-operative period was uneventful. Laparotomy confirmed the diagnosis of an omental cyst.

On gross examination, histopathology of the cystic tissue revealed that the outer surface is brown and the inner surface is smooth. The maximum thickness was $0.3 \mathrm{~cm}$. Microscopic appearance showed a fibro-collagenous cyst wall partly lined by hemosiderin laden macrophages. The wall shows granulation tissue. Multiple blood vessels infiltration of chronic inflammatory cells are seen in the wall. A large area of infarction is also seen (Fig. 6a-c). No granuloma or malignancy is seen. The diagnosis was compatible with an inflamed omental cyst.

The patient was discharged on the eighth postoperative day. After 6 months of follow-up, the patient is symptom free. 


\section{Discussion}

Different etiological factors have been proposed for development of these masses including a benign proliferation of mesenteric lymphatics, failed fusion of the mesenteric leaves, and deficiency of the lymphatico-venous shunts $[3,4]$. Other etiologic hypotheses include trauma, degeneration of the lymph nodes, and neoplasia [1]. No risk factors were found in our case. The size and the location of the cyst have an impact on the spectrum of symptoms. These cysts may present either incidentally with abdominal pain and distention and/or palpable abdominal mass [5]. This case presented with a short history of abdominal pain and distension. When these lesions are

Fig. 2. USG abdomen showing the septated mass (indicated by an arrow).

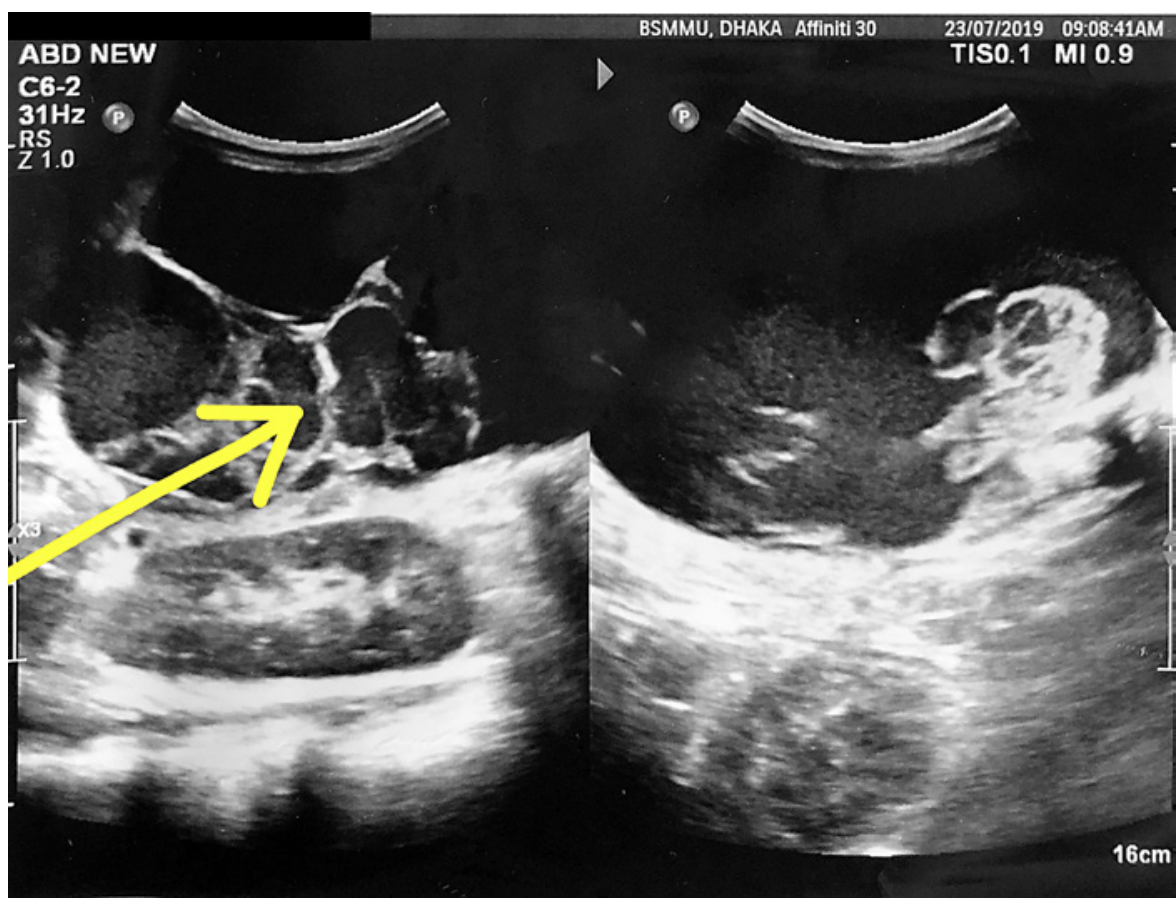

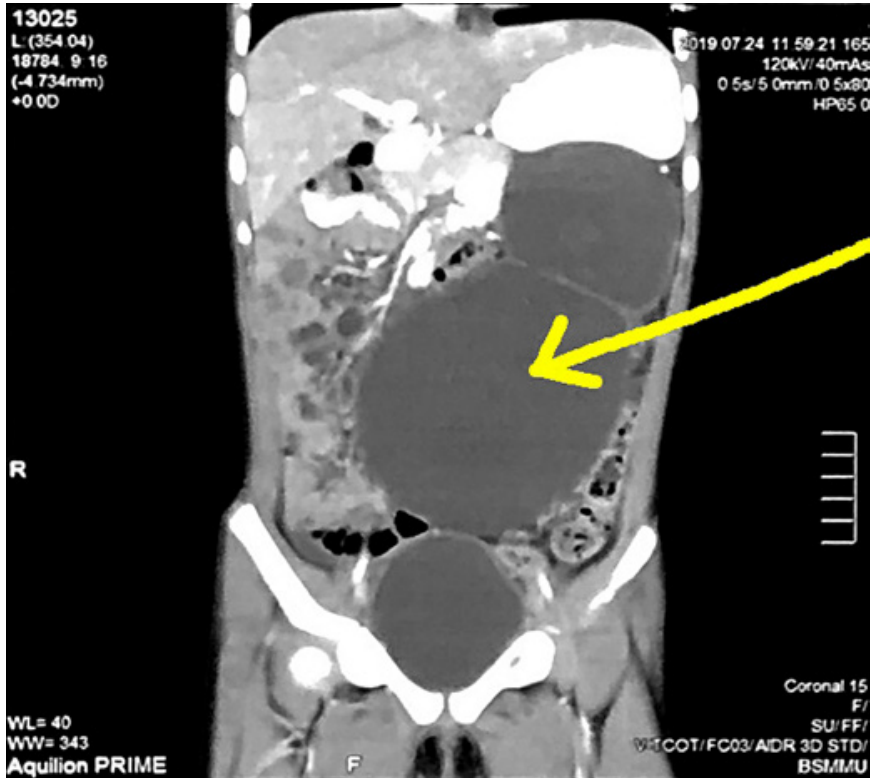

Fig. 3. CT scan abdomen showing large cyst (indicated by an arrow).

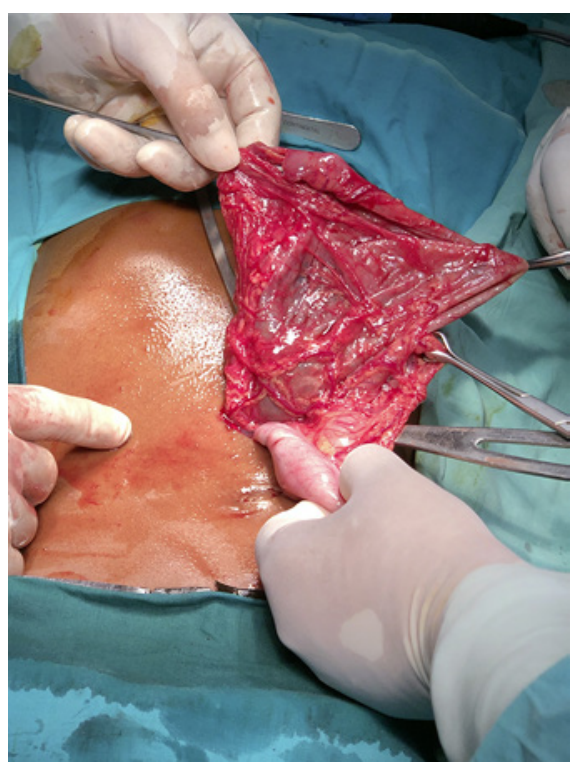

Fig. 4. Exploratory laparotomy showing the cyst wall. 
large, it can be mistaken for ascites $[6,7]$. Between 11 and $19 \%$ of patients may present with symptoms of acute abdomen due to torsion, bleeding, or rupture of the cyst. The massively enlarged cyst may cause compression of the portal vein and respiratory or urinary disorder [5]. Bowel loops are normally free-floating in ascetic fluid. Our patient presented with abdominal pain and distension. Omental cysts are restricted to the lesser or greater omentum [8]. The present case is a large omental cyst that has been developed from the greater omentum in the region of the transverse colon. Omental and mesenteric cysts can

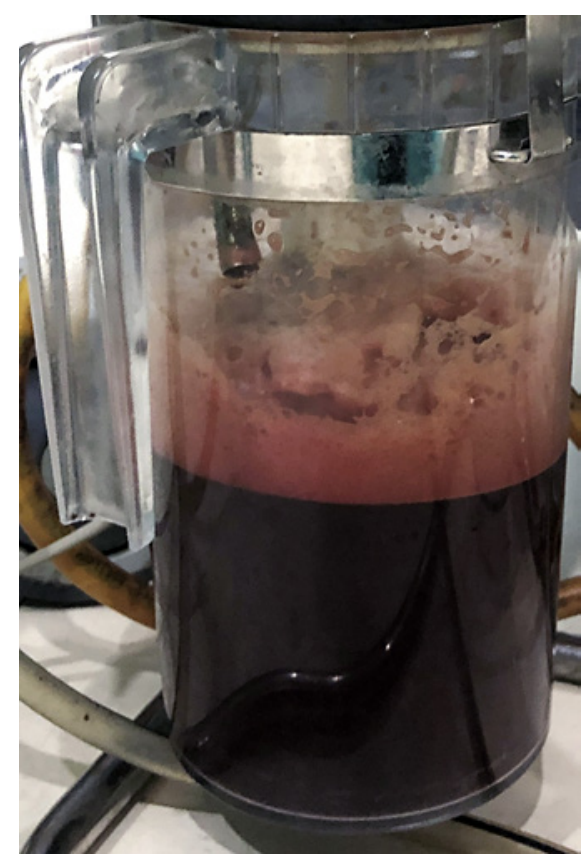

Fig. 5. Fluid from the cyst. be simple or multiple, unilocular or multilocular, may contain serous, hemorrhagic, chylous, or infected fluid [ 1 , 9]. Our patient had a multilocular cyst mass with approximately $1 \mathrm{~L}$ of hemorrhagic fluid, without solid component, and was excised. Histopathological examination revealed findings compatible with an inflamed omental cyst. Histologically omental and mesenteric cysts can be characterized by the makeup of the cyst wall. The most common type of cyst is a lymphatic malformation, followed by non-pancreatic pseudocyst, duplication cyst, mesothelial cyst, and enteric cyst [10]. Imaging modalities help diagnose these cysts preoperatively. Ultrasonogram has been reported as the initial tool in all cases. Computerized tomography (CT) and magnetic resonance imaging (MRI) may provide additional information about the extension and interior properties of the lesion $[4,11]$. Our patient underwent Ultrasonogram and CT scanning leading to the diagnosis of a mesenteric cyst. Pre-operative diagnosis is difficult. The present case reached the diagnosis after exploratory laparotomy. The preferred treatment of omental cyst is complete excision of the cyst, and resection of the bowel is rare [3]. The present case was cured by total resection of the cyst that was free of disease during the 6 months of follow-up. Even in asymptomatic patients, cystectomy is usually indicated because of the possibility of torsion, bleeding, rupture, and infection [5].

\section{Conclusion}

Omental cysts are rare conditions, but when encountering abdominal pain with or without a mass, it should be taken into consideration. The initial diagnosis should be made by performing ultrasonography and CT scan-
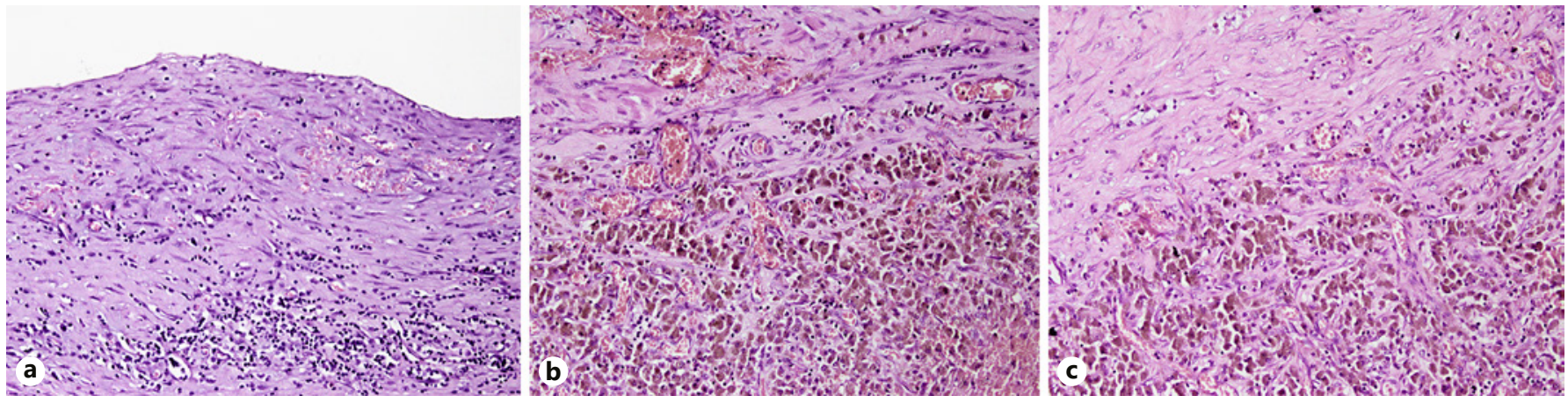

Fig. 6. a-c H\&E $\times 200$. Inflamed cyst wall. Sections show the cyst wall lined partly by granulation tissue and partly by flattened to cuboidal cells. The granulation tissue shows infiltration of chronic inflammatory cells including plasma cells and eosinophils. The cyst wall is backed by fibrocollagenous tissue. No granuloma or malignancy is seen.

Omental Cyst - Rare Cause of Abdominal Pain in a 7-Year-Old Child
GE Port J Gastroenterol 2021;28:202-206 DOI: $10.1159 / 000510022$ 
ning. After confirming the diagnosis, the main treatment would be surgical excision.

\section{Acknowledgements}

The authors gratefully acknowledge Prof. Md Ruhul Amin and Associate Prof. Abu Saleh Md. Oli Ullah, Department of Paediatric Surgery, BSMMU.

\section{Statement of Ethics}

The research was conducted ethically in accordance with the World Medical Association Declaration of Helsinki. Written informed consent was taken from the subject parents and information about revealing subject identity was avoided.

\section{Conflict of Interest Statement}

The authors have no conflicts of interest to declare.

Funding Sources

No funding was received.

\section{Author Contributions}

Maimuna Sayeed: conception of the work, sample collection, draft revising. Md Benzamin: drafting, sample collection. Sharmin Akter: draft revising. Md. Wahiduzzaman Mazumder: revising critically for important intellectual content. A.S.M. Bazlul Karim: final approval of the version to be published. Bishnu Pada Dey: analysis of the histopathological slide.

\section{References}

1 Egozi EI, Ricketts RR. Mesenteric and omental cysts in children. Am Surg. 1997 Mar; 63(3):287-90.

2 Karhan AN, Soyer T, Gunes A, Talim B, Karnak I, Oguz B, et al. Giant Omental Cyst (Lymphangioma) Mimicking Ascites and Tuberculosis. Iran J Radiol. 2016 May;13(3):e31943.

3 Pampal A, Yagmurlu A. Successful laparoscopic removal of mesenteric and omental cysts in toddlers: 3 cases with a literature review. J Pediatr Surg. 2012 Aug;47(8):e5-8.

4 Adikibi BT, Wood R, Pillay K, Millar AJ. Omental cyst presenting with profound anaemia. Afr J Paediatr Surg. 2013 Apr-Jun;10(2):180-4.
5 Uramatsu M, Saida Y, Nagao J, Takase M, Sai $\mathrm{K}$, Okumura C, et al. Omental cyst: report of a case. Surg Today. 2001;31(12):1104-6.

6 Shafi SM, Malla MA, Reshi FA. Giant primary omental cyst mimicking a pseudoascites. Afr J Paediatr Surg. 2009 Jan-Jun;6(1):58-60.

7 Menon P, Rao KL. Giant omental cyst masquerading as hemorrhagic ascites. Indian Pediatr. 2005 Apr;42(4):395-6.

8 Conzo G, Vacca R, Grazia Esposito M, Brancaccio U, Celsi S, Livrea A. Laparoscopic treatment of an omental cyst: a case report and review of the literature. Surg Laparosc Endosc Percutan Tech. 2005 Feb;15(1):33-5.
9 Vanek VW, Phillips AK. Retroperitoneal, mesenteric, and omental cysts. Arch Surg. 1984 Jul;119(7):838-42.

10 Stoupis C, Ros PR, Abbitt PL, Burton SS Gauger J. Bubbles in the belly: imaging of cystic mesenteric or omental masses. Radiographics. 1994 Jul;14(4):729-37.

11 Kokhanovsky N, Nachtigal A, Reindorp N, Shinhar D, Zeina AR. Giant omental hemorrhagic cyst presenting as acute hemorrhagic anemia in a 21-month-old infant. Pediatr Emerg Care. 2014 Mar;30(3):18890. 